\title{
Uptake of Heavy Metals by Tomato (Lycopersicum esculentus) Grown on Soil Collected from Dumpsites in Ekiti State, South West, Nigeria
}

\author{
Oluyemi Samuel Adefemi ${ }^{1}$ \& Eyitayo Emmanuel Awokunmi ${ }^{1}$ \\ ${ }^{1}$ Chemistry Department, Ekiti State University, Ado Ekiti, Nigeria \\ Correspondence: Oluyemi Samuel Adefemi, Chemistry Department, Ekiti state University, Ado Ekiti, Ekiti State, \\ Nigeria. Tel: 234-803-578-6739. E-mail: adefemisamuel@yahoo.com
}

Received: November 5, 2012 Accepted: May 13, 2013 Online Published: July 21, 2013

doi:10.5539/ijc.v5n3p70

URL: http://dx.doi.org/10.5539/ijc.v5n3p70

\begin{abstract}
People in recent times have engaged in the habit of cultivating on abadoned dunpsites or soil collected from the existing ones because of their fertility. Lycopersicun esculentus is one of the vegetables that is mostly cultivated on such sites and also commonly consumed in Nigeria. Uptake of heavy metals by tomato (Lycopersicum esculentus) grown on soil collected from dumpsites located in Ekiti State, Nigeria was determined with a view to monitoring the pollutional status of the environment. Concentration of heavy metals were found in the range of $\mathrm{Cd}$ (27.20-55.74), Co (5.18-38.15), Cr (9.30-55.40), Cu (66.67-107.00), Fe (200.01-655.90), Pb (22.32-61.60), Mn (16.90-49.20), Ni (12.06-46.60), Sn (25.90-78.99) and $\mathrm{Zn}(7.54-91.10)$ all in $\mathrm{mg} / \mathrm{kg}$. The sequence of accumulation is in order of leaf $>$ stem $>$ root $>$ fruit and Translocation factor (TF) values greater than 1 revealed that heavy metals were translocated into the aerial part of the plant. However, the study serves as pathway for the investigation of these heavy metals which may eventually enter the food chain and subsequent ingestion by man.
\end{abstract}

Keywords: Lycopersicum esculentus, dumpsites, heavy metals

\section{Introduction}

Concern has been expressed with regard to the accumulation of toxic heavy metals such as cadmium $(\mathrm{Cd})$, zinc $(\mathrm{Zn})$, copper $(\mathrm{Cu})$, chromium $(\mathrm{Cr})$, mercury $(\mathrm{Hg})$ and lead $(\mathrm{Pb})$ and their potential effects on human health, agriculture and natural ecosystems (Adefemi \& Awokunmi, 2009). Heavy metal contamination of the environment arises at all stages of metal utilization from the mining of metallic ores to the disposal of domestic and industrial wastes. Human beings, animals, vegetation and soil are the ultimate receipt for heavy metals in the environment (Ademoroti, 1996).

In Nigeria, indiscrimnate dumping of waste have become a common practice; most of the waste dumps are located close to residential areas, markets, farms and road sides. The composition of waste dumps varies widely with many human activities located close to dumpsites (Awokunmi et al., 2012). The general belief that wastes are sometimes hazardous to health cannot be over emphaized. Health risk due to heavy metal contamination has been widely reported (Baker et al., 2000; Claire et al., 1991; Duruibe et al., 2007). Crops and vegetables grown in soils contaminated with heavy metals have greater accummulation of heavy metals than those grown in uncontaminated soil (Eriyamremu et al., 2005).

Plants do not readily absorb large amount of heavy metals, and the amount they absorb depends on species and variety of plant, the chemical composition of the soil, the concentration of heavy metals and the soil $\mathrm{pH}$ among other factors. Intake of vegetables is an important path of heavy metals toxicity to human being. Dietary intake of heavy metals through contaminated vegetables may lead to various chronic diseases. The biotoxic effect of heavy metals depend upon the concentration and oxidation state of heavy metals, kind of sources and mode of deposition. Severe of cadmium may result in pulmonary effects such as emphysema, bronchiolitis and alveolitis (Fernandes \& Henriques, 1991). Lead toxicity cause reduction in haemoglobin synthesis, disturbance in functioning of kidney, joints, reproductive and cardiovascular systems and chronic damage to the peripheral nervous systems (Gardea-Torresdey et al., 1996).

Some heavy metals at low doses are essential micronutrients for plants, but in higher doses they may cause metabolic disorders and growth inhibition for most of the plants species (Goyer, 1997). The toxic effects of heavy metals in different crops may differ significantly (Komarek et al., 2008). Researchers have observed that 
some plants species are endemic to metalliferous soils and can tolerate greater than usual amounts of heavy metals or other toxic compounds. Heavy metal toxicity comprises inactivation of biomolecules by either blocking essential functional groups or by displacement of essential metal ions (Leon et al., 2002).

Therefore, the aim of this study was to determine the levels of heavy metals in various sections of Lycopersicum esculentus grown on soil collected from selected dumpsites in Ekiti State, Nigeria.

\section{Materials and Methods}

\subsection{Soil Preparation and Experimental Procedure}

Top soil $(0-15 \mathrm{~cm})$ was collected in November, 2011 from four dumpsites namely: Aba Egbira $\left(7^{\circ} 37^{\prime} \mathrm{N}\right)$, Atikankan $\left(5^{\circ} 13^{\prime} \mathrm{E}\right)$ at Ado Ekiti and Igbehin street $\left(6^{\circ} 30^{\prime} \mathrm{N}\right)$, Moshood road $\left(8^{\circ} 36^{\prime} \mathrm{E}\right)$ at Ikere Ekiti, Ekiti state, Nigeria. These soil samples were randomly collected on each dumpsite to make a total of eight soil samples (two from each dumpsite). The soil were thoroughly mixed by a mechanical mixer and passed through a $4 \mathrm{~mm}$ metal sieve to remove fiber and non soil particulate in the sample. The following soil parameters: $\mathrm{pH}$ range, organic matter content range and heavy metals concentration were determined prior to planting. $\mathrm{pH}$ and organic matter content (loss on ignition) was determined according to Muchuwiti et al. (2006).

Plastics pots of $15 \mathrm{~cm}$ in heights and $20 \mathrm{~cm}$ in diameter were filled with $5 \mathrm{~kg}$ of soil that had been previously sieved using a sieve with $4 \mathrm{~mm}$ mesh size. The seeds of these plants obtained from a farm in Ado Ekiti and identified at the Hebarium of the Plant Science Department, Ekiti State University were planted on each pot. These plants were cultivated in a green house and no fertilizer was added. Loss of water was made up using tap water. The pots were placed in individual trays to prevent loss of amendments from leaching, and the soil was irrigated to the field capacity on daily basis. The plants were harvested at maturity.

\subsection{Plant Analysis}

The plants were immersed in $0.01 \mathrm{M} \mathrm{HCl}$ solution to remove any external heavy metals and rinsed with deionized water for $1 \mathrm{~min}$. Subsequently, the plants were separated into parts: roots, stem, fruits and leaf. After that, they were dried at $100{ }^{\circ} \mathrm{C}$ for $10 \mathrm{~min}$, then at $70{ }^{\circ} \mathrm{C}$ in an oven until they were completely dried. The plants and soil samples were digested with a solution of 3:1 HNO3:HCLO4 (v/v). The concentration of heavy metals was determined using atomic absorption spectrophotometer (Perkin Elmer, model 306).

\section{Results and Discussion}

The results of concentration of ten heavy metals in the soil of selected dumpsites were shown in Table 1 with the range of $\mathrm{Cd}$ (27.20-55.74), Co (5.18-38.15), $\mathrm{Cr}$ (9.30-55.40), $\mathrm{Cu}$ (66.67-107.00), $\mathrm{Fe}$ (200.01-655.90), $\mathrm{Pb}$ (22.32-61.60), Mn (16.90-49.20), Ni (12.06-46.60), Sn (25.90-78.99) and Zn (7.54-91.10) all in mg/kg. Organic matter content and $\mathrm{pH}$ were also reported to range between 6.78-9.80\% and 6.02-6.31 respectively. It has been reported that lower $\mathrm{pH}$ value will favour availability, mobility and redistribution of heavy metals in various soil fractions (Fernandes \& Henriques, 1991). Moderate level of organic content has been reported to indicate high mineral content of soils (Ogwuegbu, 2005). The results indicated that the environment is grossly polluted with heavy metals. The high levels of these metals could be attributed to the presence of metallic waste in the industrial and municipal waste dumped in these dumpsites. Similar observations were reported by Olorunfemi and Odita (1998) while studying the impact of minicipal solid waste disposal on Ado Ekiti metropolis. 
Table 1. Mean concentration of heavy metals in soil of selected dumpsites $(\mathrm{mg} / \mathrm{kg})$

\begin{tabular}{ccccc}
\hline & $\mathrm{AB}$ & $\mathrm{AT}$ & $\mathrm{IG}$ & $\mathrm{MO}$ \\
\hline $\mathrm{Cd}$ & $27.20 \pm 6.52$ & $55.74 \pm 2.60$ & $55.09 \pm 3.94$ & $27.40 \pm 1.40$ \\
$\mathrm{Co}$ & $38.15 \pm 1.92$ & $7.90 \pm 1.10$ & $5.18 \pm 1.99$ & $12.80 \pm 2.91$ \\
$\mathrm{Cr}$ & $34.25 \pm 2.03$ & $55.40 \pm 12.87$ & $42.20 \pm 12.94$ & $9.30 \pm 1.16$ \\
$\mathrm{Cu}$ & $66.67 \pm 9.84$ & $67.26 \pm 4.72$ & $76.22 \pm 6.10$ & $107.00 \pm 8.33$ \\
$\mathrm{Fe}$ & $213.06 \pm 9.44$ & $200.01 \pm 11.22$ & $337.60 \pm 11.31$ & $655.90 \pm 3.53$ \\
$\mathrm{~Pb}$ & $40.77 \pm 3.85$ & $61.60 \pm 4.60$ & $22.32 \pm 1.28$ & $38.65 \pm 6.90$ \\
$\mathrm{Mn}$ & $46.30 \pm 2.99$ & $49.20 \pm 3.46$ & $16.90 \pm 1.74$ & $38.65 \pm 6.90$ \\
$\mathrm{Ni}$ & $46.30 \pm 2.99$ & $31.40 \pm 3.80$ & $12.06 \pm 2.04$ & $16.30 \pm 4.10$ \\
$\mathrm{Sn}$ & $51.56 \pm 6.86$ & $78.99 \pm 3.00$ & $25.90 \pm 1.61$ & $43.21 \pm 1.74$ \\
$\mathrm{Zn}$ & $11.40 \pm 2.62$ & $7.54 \pm 2.18$ & $91.10 \pm 5.94$ & $13.89 \pm 5.28$ \\
$\mathrm{pH}$ & $6.31 \pm 1.20$ & $6.22 \pm 1.10$ & $6.18 \pm 0.86$ & $6.02 \pm 0.76$ \\
$\mathrm{OMC}$ & $9.80 \pm 2.10$ & $8.60 \pm 1.64$ & $7.24 \pm 1.80$ & $6.78 \pm 1.66$ \\
\hline
\end{tabular}

Values followed by different letters differ at $\mathrm{p} \leqslant 0.05$ (LSD test).

Concentration of heavy metals in various tissues of Lycopersicum esculentus are presented in Table 2. The results showed that the leaf accumulated highest concentration of all the heavy metals studied in all dumpsites. The sequence of accumulation is in order of leaf $>$ stem $>$ root $>$ fruit. It was also revealed fromt the results that considerable concentration of heavy metals were accumulated in the shoot of Lycopersicum esculentus. Satarug et al. (2000) made similar observation when studying the accumulation of heavy metals in various tissues of Jatropha gossypifolia. The plant did not also experience yellowing of leaves that may result from phytotoxicity that may arise from considerably high concentration of heavy metals in these dumpsites. The plant grew with high biomass despite the elevated concentrations of heavy metals in these dumpsites. Sharma et al. (2007) observed that high biomass yield is another factor contributing to the increased metals uptake by plant. The result also showed that there were significant different in the concentration of heavy metals in the tissues of plant at different dunpsites at $\mathrm{p} \leq 0.05$ (LSD, test). 
Table 2. Concentration of heavy metals in the tissues of Lycopersicum esculentus planted on soil collected from selected dumpsites ( $\mathrm{mg} / \mathrm{kg}$, dry weight)

\begin{tabular}{|c|c|c|c|c|c|}
\hline & Root & Stem & Leaf & Fruit & Shoot \\
\hline \multicolumn{6}{|c|}{$\mathrm{Cd}$} \\
\hline $\mathrm{AB}$ & $4.5^{\mathrm{a}}$ & $6.2^{\mathrm{a}}$ & $12.0^{\mathrm{a}}$ & $4.4^{\mathrm{a}}$ & $22.4^{\mathrm{a}}$ \\
\hline AT & $4.0^{\mathrm{ab}}$ & $6.0^{\mathrm{a}}$ & $12.0^{\mathrm{a}}$ & $4.0^{\mathrm{a}}$ & $22.18^{\mathrm{a}}$ \\
\hline IG & $3.8^{\mathrm{b}}$ & $5.8^{\mathrm{ab}}$ & $11.8^{\mathrm{ab}}$ & $4.0^{\mathrm{a}}$ & $21.6^{\mathrm{ab}}$ \\
\hline $\mathrm{MO}$ & $3.6^{\mathrm{b}}$ & $5.8^{\mathrm{ab}}$ & $11.6^{\mathrm{ab}}$ & $3.8^{\mathrm{ab}}$ & $21.2^{\mathrm{ab}}$ \\
\hline \multicolumn{6}{|c|}{$\mathrm{Cr}$} \\
\hline $\mathrm{AB}$ & $24.0^{\mathrm{a}}$ & $56.4^{\mathrm{a}}$ & $65.1^{\mathrm{a}}$ & $10.5^{\mathrm{a}}$ & $131.0^{\mathrm{a}}$ \\
\hline AT & $20.9^{\mathrm{ab}}$ & $46.0^{\mathrm{ab}}$ & $55.4^{\mathrm{b}}$ & $9.8^{\mathrm{ab}}$ & $111.2^{\mathrm{b}}$ \\
\hline IG & $19.8^{\mathrm{b}}$ & $22.1^{\mathrm{b}}$ & $42.1^{\mathrm{c}}$ & $9.8^{\mathrm{ab}}$ & $74.0^{\mathrm{c}}$ \\
\hline $\mathrm{MO}$ & $19.6^{\mathrm{b}}$ & $20.2^{\mathrm{c}}$ & $47.2^{\mathrm{d}}$ & $7.2^{\mathrm{b}}$ & $64.6^{\mathrm{c}}$ \\
\hline \multicolumn{6}{|c|}{$\mathrm{Fe}$} \\
\hline $\mathrm{AB}$ & $40.2^{\mathrm{a}}$ & $46.5^{\mathrm{a}}$ & $70.8^{\mathrm{a}}$ & $12.5^{\mathrm{a}}$ & $129.8^{\mathrm{a}}$ \\
\hline AT & $40.0^{\mathrm{a}}$ & $42.3^{\mathrm{ab}}$ & $72.0^{\mathrm{ab}}$ & $12.0^{\mathrm{b}}$ & $126.3^{\mathrm{ab}}$ \\
\hline IG & $38.2^{\mathrm{ab}}$ & $40.4^{\mathrm{b}}$ & $70.0^{\mathrm{ab}}$ & $11.6^{\mathrm{c}}$ & $122.0^{\mathrm{b}}$ \\
\hline $\mathrm{MO}$ & $36.4^{\mathrm{ab}}$ & $31.2^{\mathrm{c}}$ & $68.6^{\mathrm{b}}$ & $10.0^{\mathrm{d}}$ & $99.8^{\mathrm{b}}$ \\
\hline \multicolumn{6}{|c|}{$\mathrm{Mn}$} \\
\hline $\mathrm{AB}$ & $20.0^{\mathrm{a}}$ & $18.2^{\mathrm{a}}$ & $62.5^{\mathrm{a}}$ & $96.4^{\mathrm{a}}$ & $177.1^{\mathrm{a}}$ \\
\hline AT & $18.6^{\mathrm{ab}}$ & $18.0^{\mathrm{a}}$ & $60.3^{\mathrm{ab}}$ & $96.2^{\mathrm{a}}$ & $174.5^{\mathrm{ab}}$ \\
\hline IG & $18.2^{\mathrm{c}}$ & $17.8^{\mathrm{ab}}$ & $56.6^{\mathrm{c}}$ & $89.1^{\mathrm{ab}}$ & $163.5^{\mathrm{bc}}$ \\
\hline $\mathrm{MO}$ & $18.2^{\mathrm{c}}$ & $17.6^{\mathrm{ab}}$ & $56.6^{\mathrm{c}}$ & $89.0^{\mathrm{ab}}$ & $163.2^{\mathrm{bc}}$ \\
\hline \multicolumn{6}{|c|}{$\mathrm{Pb}$} \\
\hline $\mathrm{AB}$ & $35.2^{\mathrm{a}}$ & $7.6^{\mathrm{a}}$ & $46.0^{\mathrm{a}}$ & $9.6^{\mathrm{a}}$ & $58.2^{\mathrm{a}}$ \\
\hline AT & $35.0^{\mathrm{a}}$ & $7.5^{\mathrm{a}}$ & $46.2^{\mathrm{a}}$ & $9.2^{\mathrm{a}}$ & $53.2^{\mathrm{a}}$ \\
\hline IG & $28.7^{\mathrm{b}}$ & $7.2^{\mathrm{b}}$ & $45.0^{\mathrm{ab}}$ & $9.0^{\mathrm{a}}$ & $61.2^{\mathrm{ab}}$ \\
\hline $\mathrm{MO}$ & $28.3^{\mathrm{b}}$ & $70.0^{\mathrm{c}}$ & $45.0^{\mathrm{ab}}$ & $9.6^{\mathrm{a}}$ & $61.6^{\mathrm{ab}}$ \\
\hline \multicolumn{6}{|c|}{$\mathrm{Zn}$} \\
\hline $\mathrm{AB}$ & $16.6^{\mathrm{a}}$ & $12.0^{\mathrm{a}}$ & $32.4^{\mathrm{a}}$ & $12.4^{\mathrm{a}}$ & $56.8^{\mathrm{a}}$ \\
\hline AT & $15.8^{\mathrm{b}}$ & $18.4^{\mathrm{b}}$ & $30.6^{\mathrm{ab}}$ & $106^{\mathrm{ab}}$ & $59.6^{\mathrm{ab}}$ \\
\hline IG & $14.2 b^{c}$ & $18.0^{\mathrm{c}}$ & $30.0^{\mathrm{ab}}$ & $10.3^{\mathrm{ab}}$ & $58.3^{\mathrm{ab}}$ \\
\hline $\mathrm{MO}$ & $14.2 b^{c}$ & $17.0^{\mathrm{bc}}$ & $28.6^{\mathrm{b}}$ & $10.6^{\mathrm{c}}$ & $56.2^{\mathrm{bc}}$ \\
\hline \multicolumn{6}{|c|}{$\mathrm{Ni}$} \\
\hline $\mathrm{AB}$ & $12.1^{\mathrm{a}}$ & $5.8^{\mathrm{a}}$ & $16.4^{\mathrm{a}}$ & $2.6^{\mathrm{a}}$ & $24.8^{\mathrm{a}}$ \\
\hline AT & $12.1^{\mathrm{a}}$ & $5.6^{\mathrm{ab}}$ & $16.4^{\mathrm{a}}$ & $2.6^{\mathrm{a}}$ & $24.6^{\mathrm{a}}$ \\
\hline IG & $11.8^{\mathrm{ab}}$ & $5.2^{\mathrm{ab}}$ & $15.8^{\mathrm{b}}$ & $2.3^{\mathrm{b}}$ & $23.3^{\mathrm{ab}}$ \\
\hline $\mathrm{MO}$ & $11.7^{\mathrm{bc}}$ & $5.0^{\mathrm{c}}$ & $15.8^{\mathrm{b}}$ & $1.9^{\mathrm{c}}$ & $22.7^{\mathrm{c}}$ \\
\hline \multicolumn{6}{|c|}{$\mathrm{Cu}$} \\
\hline $\mathrm{AB}$ & $26.0^{\mathrm{a}}$ & $18.4^{\mathrm{a}}$ & $28.4^{\mathrm{a}}$ & $26.8^{\mathrm{a}}$ & $73.6^{\mathrm{a}}$ \\
\hline AT & $26.1^{\mathrm{a}}$ & $18.2^{\mathrm{a}}$ & $28.8^{\mathrm{a}}$ & $22.5^{\mathrm{ab}}$ & $69.5^{\mathrm{a}}$ \\
\hline IG & $25.8^{\mathrm{b}}$ & $18.0^{\mathrm{a}}$ & $27.2^{\mathrm{ab}}$ & $20.6^{\mathrm{b}}$ & $65.8^{\mathrm{ab}}$ \\
\hline $\mathrm{MO}$ & $11.09^{\mathrm{a}}$ & $2.8^{\mathrm{b}}$ & $3.0^{\mathrm{b}}$ & $5.5^{\mathrm{b}}$ & $11.3^{\mathrm{b}}$ \\
\hline \multicolumn{6}{|c|}{$\mathrm{Co}$} \\
\hline $\mathrm{AB}$ & $11.2^{\mathrm{a}}$ & $3.2^{\mathrm{a}}$ & $4.2^{\mathrm{a}}$ & $6.0^{\mathrm{a}}$ & $13.4^{\mathrm{a}}$ \\
\hline AT & $11.2^{\mathrm{a}}$ & $3.0^{\mathrm{a}}$ & $4.0^{\mathrm{a}}$ & $6.0^{\mathrm{a}}$ & $13.0^{\mathrm{a}}$ \\
\hline IG & $11.0^{\mathrm{a}}$ & $2.8^{\mathrm{b}}$ & $3.8^{\mathrm{b}}$ & $5.6^{\mathrm{b}}$ & $12.2^{\mathrm{b}}$ \\
\hline $\mathrm{MO}$ & $11.0^{\mathrm{a}}$ & $2.8^{\mathrm{b}}$ & $3.0^{\mathrm{b}}$ & $5.5^{\mathrm{b}}$ & $11.3^{\mathrm{b}}$ \\
\hline \multicolumn{6}{|c|}{$\mathrm{Sn}$} \\
\hline $\mathrm{AB}$ & $12.2^{\mathrm{a}}$ & $3.6^{\mathrm{ab}}$ & $4.2^{\mathrm{a}}$ & $1.8^{\mathrm{a}}$ & $9.6^{\mathrm{a}}$ \\
\hline AT & $10.1^{\mathrm{ab}}$ & $3.2^{\mathrm{a}}$ & $4.1^{\mathrm{a}}$ & $1.2^{\mathrm{b}}$ & $8.5^{\mathrm{ab}}$ \\
\hline IG & $10.0^{\mathrm{ab}}$ & $3.2^{\mathrm{a}}$ & $3.8^{\mathrm{b}}$ & $1.0^{\mathrm{b}}$ & $8.0^{\mathrm{ab}}$ \\
\hline $\mathrm{MO}$ & $10.0^{\mathrm{ab}}$ & $2.8^{\mathrm{b}}$ & $3.0^{\mathrm{b}}$ & $5.5^{\mathrm{b}}$ & $11.3^{\mathrm{b}}$ \\
\hline
\end{tabular}

AB: Aba Egbira; AT: atikankan; IG: Igbehin; MO: Moshood.

Values with the same superscript did not vary significantly at $\mathrm{p} \leq 0.05$. 
Translocation factor (TF) of heavy metals in plants grown on contaminated soil is the quotient of contaminant concentration in shoot to root (TF), which is used to measure the effectiveness of plant in transferring a chemical pollutant from roots to shoots (Sun et al., 2009). TF greater than 1 shows the ability of plant to translocate heavy metals from roots to shoot. Table 3 revealed that for all the metals investigated, TF values were greater than 1 except for Sn that has value less than 1 in all dumpsites.

Table 3. Translocation factor of heavy metals in Lycopersicum esculentus

\begin{tabular}{ccccccccccc}
\hline & $\mathrm{Cd}$ & $\mathrm{Cr}$ & $\mathrm{Fe}$ & $\mathrm{Mn}$ & $\mathrm{Pb}$ & $\mathrm{Zn}$ & $\mathrm{Ni}$ & $\mathrm{Cu}$ & $\mathrm{Co}$ & $\mathrm{Sn}$ \\
\hline $\mathrm{AB}$ & 5.0 & 5.5 & 3.2 & 8.9 & 1.7 & 3.4 & 2.0 & 2.8 & 1.2 & 0.8 \\
$\mathrm{AT}$ & 5.5 & 5.3 & 3.2 & 9.4 & 1.5 & 3.8 & 2.0 & 2.7 & 1.2 & 0.8 \\
$\mathrm{IG}$ & 5.7 & 3.7 & 3.2 & 8.9 & 2.1 & 4.1 & 2.0 & 2.6 & 1.1 & 0.8 \\
$\mathrm{MO}$ & 5.9 & 3.3 & 2.7 & 8.9 & 2.2 & 4.0 & 1.9 & 2.6 & 1.0 & 0.8 \\
\hline
\end{tabular}

\section{Conclusion}

The study revealed the use of as a potential plant Lycopersicum esculentus as a candidate for monitoring of pollution status of the environment. The dumpsites under investigation were grossly polluted with heavy metals and that these metals were found in various plant tissues. The TF values greater than 1 showed the ability plant to successfully translocate heavy metals from the shoot to root, thereby making the plant a potential candidate for environmental restoration. Consumption of vegetable with elevated levels of heavy metals may cause related health disorders. Thus regular monitoring of heavy metal concentration in the environment, most importantly dumpsites is necessary.

\section{References}

Adefemi, O. S., \& Awokunmi, E. E. (2009). The impact of municipal solid waste disposal in Ado Ekiti metropolis, Ekiti State, Nigeria. Afri J. of Environ. Sci. and Tech., 3(8), 186-191.

Ademoroti, C. M. A. (1996). Standard methods of chemical analysis (pp. 45). March Print and Consultancy Benin, Nigeria.

Awokunmi, E. E., Asaolu, S. S., Ajayi, O. O., \& Adebayo, O. A. (2012). The role of EDTA on heavy metals phytoextraction by Jatropha gossypifolia grown on soil collected from dumpsites in Ekiti state, Nigeria. British J. of Envi. and Climate Change, 2(2), 153-162.

Baker, A. J. M., McGrath, R. D., \& Smith, J. A. C. (2000). Metal Hyperaccumulators plants: A review of the ecology and physiology of a biological resource for phytremediation of metal-polluted soils. In N. Tarry, \& G. Banuelos (Eds.), Phytoremediation of contaminatedsoil, 6, 22-26.

Claire, L. C., Adriano, D. C., Sajwan, K. S., Abel, S. L., Thoma, D. P., \& Driver, J. T. (1991). Effects of selected trace metals on germinating seeds of six plant species. Water Air Soil Pollut., 59, 231-240. http://dx.doi.org/10.1007/BF00211832

Duruibe, J. O., Ogwuegbu, M. D. C., \& Egwurugwu, J. N. (2007). Heavy metals pollution and human biotixic effects. Int. J. Physical Sci., 2, 112-118.

Eriyamremu, G. E., Asagba, S. O. Akpoboro, A., \& Ojeaburu, S. I. (2005). Evaluation of lead and cadmium levels in some commonly consumed vegetables in Niger Delta Oil area of Nigeria. Bulletin of Environmental Contamination and Toxicology, 75, 278-283. http://dx.doi.org/10.1007/s00128-005-0749-1

Fernandes, J. C., \& Henriques, F. S. (1991). Biochemical, physiological, and structural effects of excess copper in plants. Bot. Rev., 57, 246-273. http://dx.doi.org/10.1007/BF02858564

Gardea-Torresdey, J. L., Polette, L., Arteaga, S. K., Tiemann, J., Bibb, J. J., \& Gonzalez, H. (1996). Determination of the content of hazardous heavy metals on Larrea tridentata grown around a contaminated area. In Proceedings of the Eleventh Annual EPA Conf. On Hazardous Waste Research.

Goyer, R. A. (1997). Toxic and essential metal interactions. Ann. Rev. Nutr., 17, 37-50. http://dx.doi.org/10.1146/annurev.nutr.17.1.37

Hong, C., \& Teresa, C. (2001). EDTA and HEDTA effects on Cd, Cr and Ni uptake by Helianthus annus. Chemosphere, 45, 21-28. http://dx.doi.org/10.1016/S0045-6535(01)00031-5 
Komárek, M., Tlustoš, P., Száková, J., \& Chrastny, V. (2008). The use of poplar during a two year induced phytoextraction of metals from contaminated agricultural soils. Environ. Pollut., 151, 27-38. http://dx.doi.org/10.1016/j.envpol.2007.03.010

León, A. M., Palma, J. M. Corpas, F. J., Gómez, M., Romero-Puertas, M. C., Chatterjee, D. R., ... Sandalio, L. M. (2002). Antioxidative enzymes in cultivars of pepper plants with different sensitivity to cadmium. Plant Physiol. Biochem., 40, 813-820. http://dx.doi.org/10.1016/S0981-9428(02)01444-4

Muchuwiti, M. J. Birkett, W. Chinyanga, E., Zvauya, R., Scrimshaw, M. D., \& Lester, J. N. (2006). Heavy metals content of vegetable irrigated with mixture of waste water and sewage sludge in Zimbabwe. Implications for Human health, Agriculture, Ecosystem and Environment, 112, 41-48. http://dx.doi.org/10.1016/j.agee.2005.04.028

Ogwuegbu, M. O. C., \& Muhanga, W. (2005). Investigation of lead concentration in the blood of people in copper belt province of Zambia. J. Environ., 1, 66-75.

Olorunfemi, J. F., \& Odita, C. O. (1998). Land use and solid waste generation in Ilorin, Kwara State, Nigeria. The Environmentalist, 18, 67-75. http://dx.doi.org/10.1023/A:1006614206361

Satarug, S., Heswell-Eilkins, M. R., \& Moore, M. R. (2000). Safe level of camium intake to prevent renal toxicity of human subjects. British Journal of Nutrition, 84, 791-802.

Sharma, R. K., Agrawal, M., \& Varshal, S. (2007). Heavy metals contamination in vegetables grown in waste irrigated areas of Varanasi, India. Bulletin of Environmental Contamination and Toxicology, 77, 311-318.

Sun, Y. B., Zhou, Q., Wang, X. L., \& Liu, W. T. (2009). The influence of different growth stages and dosage of EDTA on Cd uptake and accumulation in Cd-hyperaccumulator (Solanium nigrum L.). Bull. Environ. Contam. Toxicol., 82, 348-353. http://dx.doi.org/10.1007/s00128-008-9592-5

\section{Copyrights}

Copyright for this article is retained by the author(s), with first publication rights granted to the journal.

This is an open-access article distributed under the terms and conditions of the Creative Commons Attribution license (http://creativecommons.org/licenses/by/3.0/). 